\section{EVALUATION OF IMPACT OF EXISTING EXTRA CURRICULAR ACTIVITIES AT UNDERGRADUATE MEDICAL AND DENTAL EDUCATION IN BANGLADESH}

Md. Humayun Kabir Talukder' ${ }^{1}$, Mohammad Faruque², Kazi Khairul Alam ${ }^{3}$, Tahmina Nargis ${ }^{4}$, Syed Md Akram Hussain ${ }^{5}$, Md. Zakir Hossain ${ }^{6}$, Rumana Nazneen ${ }^{7}$, Md. Zubaidur Rahman $^{8}$

\section{Abstract:}

With an objective to evaluate the impact of existing extracurricular activities at undergraduate medical and dental education in Bangladesh this descriptive study was designed and collected information conveniently from 515 students and 155 teachers from randomly selected medical and dental colleges of the country. The respondents (100\%) supported more than one extracurricular activity for the medical and dental students. More than $65 \%$ were in favor of games, sports and cultural functions. Some students clubs are also popular among the respondents but only $10.8 \%$ respondents supported student politics. The respondents who were against student politics viewed that it hamper educational activities and disciplines in their institutes. About half the respondents (48.8\%) were unsatisfied with the present academic activities in their medical colleges. Respondents advised to develop infrastructures, accommodation facilities, teaching aids, libraries, administrative supervisory in the institutes. They also demand more trained teachers, good students-teachers relationship to raise standard of the medical and dental colleges to a satisfactory level.

Key words: Extracurricular activities, Evaluation, Impact.

\section{Introduction:}

Extra curricular activities are those activities performed by students that fall outside the realm of the normal curriculum of an institute. Extracurricular activities exist at all levels of education, from primary to university education. Such activities are generally voluntary as opposed to mandatory. This is done by students associations, student chapters and individually. Students often organise and direct these activities under faculty sponsorship and supervision ${ }^{1,2}$.

1. Associate Professor, Centre for Medical Education (CME), Mohakhali, Dhaka.

2. Associate Professor, Dentistry, Dhaka Dental College, Dhaka

3. Lecturer, Centre for Medical Education, Dhaka.

4. Lecturer, Centre for Medical Education, Dhaka

5. Professor and Chairman, Department of Oncology, BSMMU.

6. Research Assistant, Centre for Medical Education, Dhaka

7. Assistant Prof, OBGYN, HFRCMC

8. Assistant Professor, Forensic Medicine, OSD, DGHS, Dhaka
Education is not solely learned by reading the textbook. Students can learn an incredible amount from their peers through extracurricular activities. Students learn how to compromise and work in a group. Activities such as athletics, music, theater and organisations teach students how to discipline themselves through drills, practices, or rehearsals. By participating and persevering in any of these activities, the students gain a sense of self-respect, self-esteem, and selfconfidence. Extracurricular activities give them pride in their accomplishments and they learn that if an activity is worth doing, it is worth doing well. These team sprits are an excellent way to build character-4.

Extra curricular activities are very helpful for physical and mental fitness and refreshment of the students. These are very useful to bring out latent talent of students. These also help students in personality development and grow leadership among them. It provide additional field of knowledge beyond academic activities. A recent research demonstrate that extra curricular activities are also useful, effective in prevention of violence and drug use among students if it is supervised by parents and teachers. Even that some educators felt that less desirable extracurricular activities were now distracting students from their curricular responsibilities. So there will be some rules and supervision of extracurricular activities so that it will be complimentary to education ${ }^{5-9}$.

In most of the institutes extracurricular activities run throughout the year. Students engaged in extracurricular activities highly at the end of their examination when curricular activities are minimum. These are minimum when students are busy with their examinations and preparation for examination. Like other institutes medical students of Bangladesh they are also involved in a lot of extracurricular activities ${ }^{10}$.

No research yet been conducted about the present status of extra curricular activities in medical and dental colleges of Bangladesh. The present research was aimed to know the present situation of extracurricular activities at undergraduate medical and dental education in Bangladesh through getting views of the teachers and students about it. Findings of the research can be used for better policy decision for improvement of medical and dental education of Bangladesh by promoting extra curricular activities which have positive impact on medical education and minimizing the unwanted extra curricular activities which have negative impact on medical and dental education of Bangladesh; which will ensure better \& improved academic environment and will ultimately ensure the effective, competent \& desired health care delivery in Bangladesh..

\section{Methodology:}

This descriptive study was conducted among the students and teachers of medical and dental colleges of Bangladesh. 
The pretested self-administered questionnaires having closeended questions mostly with few open-ended questions were mailed to the focal persons of randomly selected medical and dental colleges of Bangladesh. Then all questionnaire were send to the concerned department for answering by students and other teachers for colleting data. Teachers who attended the different workshops conducted at CME were given the questionnaire to response. Ultimately a total of 670 respondents of which 515 students and 155 teachers participated in this study.

\section{Results:}

Initially the respondents were grouped in different categories and then their responses in the structured form were given in different tables. Lastly the response in the unstructured form were summarized as per convenience for easy understanding of the readers.

Table-I: Distribution of respondents by demographic features $n=670$

\begin{tabular}{lc}
\hline Categories & N (\%) \\
\hline Category of medical and dental colleges & $665(99.3)$ \\
Government & $5(0.7)$ \\
Non Government & \\
Gender of respondents & $293(43.7)$ \\
Male & $377(56.3)$ \\
Female & \\
& \\
Category of respondents by rank & $155(23.1)$ \\
Teacher & 25 \\
Prof. & 30 \\
Assoc. Prof. & 52 \\
Asstt. Prof. & 48 \\
Lecturer/MO & \\
& $515(76.9)$ \\
Student & 139 \\
5th year & 220 \\
4th year & 156 \\
3rd year &
\end{tabular}

Out of 670 respondents only $5(0.7 \%)$ were from nongovernment medical colleges and rests 665 (99.3\%) belonged to government institutes. Female participants were more (56.3\%) than the male participants (43.7\%). Of 670 respondents majority (76.9\%) were students and rest $23.1 \%$ were teachers. Teachers of different rank responded in this study. Among the students only views of fourth year, fifth year, and third academic year were taken. Students of first year and second years were excluded as it was assumed that they might have inadequate experience about different academic aspect.
Table-II: Distribution of respondents as per their satisfaction with the present academic environment of their medical colleges. $n=670$

\begin{tabular}{lccc}
\hline Respondents' Satisfaction & $\begin{array}{c}\text { Students } \\
\text { N(\%) }\end{array}$ & $\begin{array}{c}\text { Teachers } \\
\text { N (\%) }\end{array}$ & $\begin{array}{c}\text { Total } \\
\text { N(\%) }\end{array}$ \\
\hline Satisfied & $258(50.1)$ & $85(54.84)$ & $343(51.2)$ \\
Unsatisfied & $257(49.9)$ & $70(45.2)$ & $327(48.8)$ \\
\hline
\end{tabular}

All most equal number of respondents were satisfied 343 (51.1\%) with the present academic environment in their medical colleges compared to unsatisfied 327 ( 48.8\%) group.Among students equal number of were satisfied (50.1\%) as compared to unsatisfied (49.9\%) group of students with the present academic environment in their medical colleges. Similarly teachers who were satisfied (54.8\%) did not differ widely in percentage as compared to unsatisfied (45.2\%) group of teachers.

Table-III: Distribution of respondents opinions about extra curricular activities. in which medical and dental students should be involved beside their academic activities $n=670$

\begin{tabular}{lc}
\hline Category of respondents & $\mathrm{N}(\%)$ \\
\hline Games & $434(64.8)$ \\
Sports & $455(68.0)$ \\
Cultural function & $437(65.3)$ \\
Limited social welfare & $260(38.8)$ \\
Leo club & $66(9.9)$ \\
Rotary club & $166(24.8)$ \\
Shandhani (club) & $271(40.5)$ \\
Medicine club & $146(21.8)$ \\
Students politics & $36(5.4)$ \\
Others & $30(4.5)$ \\
All above & $36(5.4)$ \\
\hline
\end{tabular}

All (100\%) respondents chose more than one extracurricular activities in medical colleges. Major parts of the respondents preferred sports (68\%), cultural functions (65.3\%) and games (64.8\%). Very few (5.4\%) respondents chose student politics in these institutes. Shandhani was most (40.5\%) popular among students club. Rotary club (24.8\%), Medicine club (21.8\%), Leo club (9.9\%) also chose. Only 5.4\% respondents chose all above, and $4.5 \%$ chose other activities.

Table-IV: Distribution of respondents' opinions whether medical and dental students can take part directly in political activities in addition to their usual academic activities $n=670$

\begin{tabular}{lc}
\hline Opinion about political activities & Frequency (\%) \\
\hline Students could be involved & $78(11.6)$ \\
Students should not involved & $592(88.4)$ \\
\hline
\end{tabular}


Table-IV have been showing that majority (88.4\%) of respondents viewed that students should not involved in political activities, while only $11.6 \%$ respondents viewed that students could be involved in political activities in addition to their usual academic activities in medical and dental colleges.

There were some open-ended questions to specify the reasons behind their answer. Most of the students' did not respond to the open ended questions, on the other hand majority of the teachers did it. The answers to the open-ended questions were very much diverse. The response was grouped

Good administration, good teaching system and systematic examination, regular academic session, positive attitude, punctuality and sincerity of teachers and staffs or students are few reasons for which some respondents were satisfied with the present academic environment. Few respondents were also satisfied due to most of the teachers are postgraduate holder, adequacy learning materials, and good teachers students relationship.

Space shortage for classes and academic activities, shortage of teachers especially skilled teachers, inadequate teaching aids, traditional examination systems, insecurity, lack communication between higher and lower management, poor relationship between teachers and students are some of the reasons for which some respondents were not satisfied with the present academic environment. Again some these respondents were not satisfied as because irregularity of teachers, lack of administrative and academic supervision, political activities of some teachers and students, posting of specialists / experts as teachers in different subjects, and the jobs of the 4th class employee are not transferable.

Similarly respondents mentioned several factors responsible for disturbance of academic activities in their medical and dental colleges. These factors are political unrest of the country and political activities of some medical and dental students and teachers, shortage of teachers, classroom, teaching aids, auxiliary staffs, poor residential facilities for students even for the teachers, inadequacy spaces for academic activities, posting of another subject specialist other than the concerned subject as a lecturer. Shortage of skilled and trained teachers, drug abuse among students, poor administration and hence lack of accountability and lack of transparency, less responsibility of teachers and their poor interest in academic activities as are busy with clinical practices outside, poor devotion and commitment to study of the students, wrong evaluation system and lack of reward for good performer and punishment for defaulter, Influence of pressure groups on assessment, poor relationship between teachers and students are also responsible for disturbance of academic activities in the medical colleges.
Some respondents viewed that students should not be involved in politics because: it divides students, damage their relationship and creates violence among them, the students involved in politics and their politicians hamper normal academic activities and disciplines; create illegal pressure on teachers and assessment; as the course is vast so student have not enough time to be involved in politics logically. As political environment of the country is not good, it create terrorist and damage valuable life. The main target of medical students is to serve people being a good doctor not to serve as politician.

A hues number of suggestion was given by the respondents to improve the academic environment. Those are: Teachers should be more sincere and committed to teaching. Number of classrooms, qualified teachers should be increased. There should be more teaching aids and library should be rich in all aspects. Authority should monitor the activities of subordinates regularly they should be adequate. There should be more incentives for sincere teachers and students. Liaison and communication between lower and higher management teachers and students should be adequate and effective. Academic calendar should be strictly maintained. Traditional examination system should be changed. Regular meting of the academic council should be held. Student politics should be stopped. Teachers should be trained up on own subject and modern teaching methods. Sufficient equipment, scope, time should be available for extra curricular activities. Hostel facilities should be adequate. Disturbance from outsider should be stopped. Progress report of the students should be sent to guardians regularly. Pressure from outside should be eliminated in assessment and examinations. Private practice by academic teachers should be prohibited and non-practicing allowances should be given. Political activities in the institute by the students as well as by teachers should be prohibited or at least it should be minimised.

\section{Discussion:}

The one of the major functions of Centre for Medical Education (CME), Dhaka is to evaluate existing academic activities in medical, dental , paramedical and nursing institutes of Bangladesh and to make necessary recommendations as per the finding and lacunae in those areas. With this point of view the present research focused to find out extracurricular activities that are prevailing in the medical and dental colleges of Bangladesh, the impact of these on academic activities, thorough analysis of views of the students and teachers. This study designed to find out their preference and suggestion regarding extracurricular activities. This study also extended to identify the present status at academic environment of medical and dental colleges and factors affecting them and to find out specific suggestions to improve it.

The study tried to represent the medical and dental colleges of all over the country. So medical and dental colleges were selected randomly from the mainly government colleges. There 
was little scope to select the respondents other than purposively in those institutes. Because, each and every teachers and students were not available in the concern institutes during the period of data collection.

The study find out that all respondents (100\%) supported some kind of extra curricular activities in the medical and dental colleges whether only 5.4\% supported students politics. Again when the same respondents were asked whether medical students can take parts in students politics $88.4 \%$ gave negative answer and $11.6 \%$ game answer in favor it.

It was found that almost equal number of respondents viewed that they are satisfied with the present academic activities in their institutes. This finding indicates that our medical colleges are not with very poor performance. But a lot of efforts are needed to improve their status.

Al responses to the open-ended questions focus on 6 major aspects. These are:

$\begin{array}{ll}\text { 1. } & \text { Administrative } \\ \text { 2. } & \text { Academic } \\ \text { 3. } & \text { Political } \\ \text { 4. } & \text { Legal } \\ \text { 5. } & \text { Financial support } \\ \text { 6. } & \text { Hunan relation }\end{array}$

Administrative: Majority of respondents viewed indicate they are in need of good administration both at institute level, and national level in terms of supervision, monitoring, accountability, and transparency.

Academic: Respondent argued for good academic environments in terms of learned and trained teachers, teaching and library facilities, adequate class room and spaces for academic activities, good support of auxiliary stuffs.

Political: Except few, majorities of the respondents were in disfavor of political activities in their medical and dental colleges as it hamper academic activities.

Legal: Few informants opined that political activities and activities of outsider should be eliminated and posting and transfer posting of lecturer and 4th class employee should be in favor of the academic environment.

Financial: It is needed for extension of academic and hostel buildings, purchase of learning and teaching aids, to provide more training and intensives to the teachers etc.

Human relation: This study indicates that undergraduate medical and dental colleges are need of more collaboration between administrators, teachers, students, and stuffs for developing a good academic environment.

\section{Conclusion:}

Students of Bangladesh are involved in politics and they create history and are honored by people of the country for their active participation in different political crisis and disaster. For the rapid development of the country we have to raise our expertise in our own fields. The participants viewed that medical students should be involved in their lesson to be good doctors rather than involving in politics. Majority of them supported some kind of extracurricular activities except student's politics. Again it was opined that students politics as well as political exercise by the teachers hampering normal academic activities. The study find out that about half of teachers and students are not satisfied with the present academic environment in medical and dental colleges. There were several suggestions from the teachers and students to solve several problems they have mentioned.

\section{Acknowledgement:}

The authors are thankful to the Director Planning and Research, DGHS, and World Bank (WB) for giving the technical and financial support. They would also like to offer their sincere and heartily thanks to the Director, CME and all staffs of Centre for Medical Education (CME), for their continuous efforts. They express their gratitude to principals, teachers and students of different medical and dental colleges who were kind enough to co-operate during activity at the field level.

\section{References:}

1. Curricular and extracurricular activities of medical students during war, Zagreb University School of Medicine, 1991-1995.

2. Toward Curriculum Improvement: Cooperative Curriculum Development: A Symposium: The Role of Pupils in Cooperative Curriculum Development by Teachers College Department of Curriculum and Teaching - 1949

3. Adam Gamoran 1997, Curriculum Change as a Reform Strategy: Lessons from the United States and Scotland

4. Curriculum and Aims \& Curriculum: Prespective, Paradigm, and Possibility reviewed by Michael W. Apple \& Ralph Tyler - 1987

5. The Curriculum of the Elementary School: The Curriculum of the Horace Mann Elementary School by Samuel T Dutton \& Henry C. Pearson -1904

6. Perry CL, Komro KA, Veblen-Mortenson S. et al. A Randomized controlled trial of the middle and junior high school D.A.R.E. and D.A.R.E. Plus programs. Arch Pediatr Adolesc Med. 2003; 157: 178-184.

7. Basic Principles of Curriculum and Instruction. Ralph W. Tyler. University of Chicago Press, Cicago.

8. A curriculum for life: School for a demographic Society. John Quike. Open University Press, Philadelphia.

9. Curriculum Design. Edited by Michal Golby, Jane Green wald Ruth West. Open University Press, London.

10. Curriculum Innovation: A celebration of classroom practice. Rogern Crombie White. Open University Press, Philadelphia. 